24 Nugent JA, Schurr KA, Adams RD. A doseresponse relationship between amount of weight-bearing exercise and walking outcome following cerebrovascular accident. Arch Phys Med Rehabil 1994; 75: 399-402.

25 Abel NA, Smith RA. Intrathecal baclofen for treatment of intractable spinal spasticity. Arch Phys Med Rehabil 1994; 75: 54-8.

26 Skeil DA, Barnes MP. The local treatment of spasticity. Clin Rehabil 1994; 8: 240-6.

27 Hesse S, Friedrich H, Domasch C, Mauritz K-H. Botulinum toxin therapy for upper limb flexor spasticity: preliminary results. $\mathcal{f}$ Rehabil Sci 1992; 5: 98-101.

28 Levin MF, Hui-Chan CW. Relief of hemiparetic spasticity by TENS is associated with improvement in reflex and voluntary motor functions. Electroencephalogr Clin Neurophysio

29 Sonnen VG. Segmental reflex therapy for neurogenic contractures - a clinical study. Clin Rehabil 1992; 6: 341-4.
30 Hines AE, Crago PE, Billian C. Functional electrical stimulation for the reduction of spasticity in the hemiplegic hand. Biomed Sci Instrum 1993; 29: 259-66.

31 Kraft GH, Fitts SS, Hammond MC. Techniques to improve function of the arm and hand in chronic hemiplegia. Arch Phys Med Rehabil 1992; 73: 220-7.

32 Ben-Yishay Y, Diller L. Cognitive remediation in traumatic brain injury: update and issues. Arch Phys Med Rehabil 1993; 74: 204-13.

33 Warnock $\mathrm{H}$, Northin D, Carberry S, et al. Head injury: developing community occupational injury: developing community occupational 1992; 55: 99-102.

34 Greenwood RJ, McMillan TM, Brooks DN, et al. Effects of case management after severe head al. Effects of case management after

35 Aung TS, Boughey A, Ward AB. A study of the North Staffordshire young adult service for the physically handicapped school leaver and young adult. Clin Rehabil 1994; 8: 247-52.
36 Newell KM. Motor skill acquisition. Annu Rev Psychol 1991; 42: 213-37.

37 Wann JP, Turnbull JD. Motor skill learning in cerebral palsy: movement, action and computerenhanced therapy. Baillieres Clin Neurol 1993; 2: $15-28$

38 McLellan DL. Rehabilitation. BMf 1991; 303: 355-7.

39 Robertson IH, Gray JM, Pentland B, Waite LJ. Microcomputer-based rehabilitation for unilateral left visual neglect: a randomized controlled trial. Arch Phys Med Rehabil 1990; 71: 663-8.

\title{
Medical Anniversary JOHN FARQUHAR FULTON, 1 NOVEMBER 1899
}

John Farquhar Fulton (1899-1960) was born at St Paul, Minnesota, USA, the son of an ophthalmologist. He was educated at Harvard, came to Magdalen College Oxford as a Rhodes Scholar and, under the influence of Sherrington, became a neurophysiologist. He graduated MD from Harvard (1927) and became FRCP (1953). He became professor of physiology, and later professor of the history of medicine, at Yale. He will also be remembered for his outstanding biography of Harvey Cushing. - D Geraint fames 